Vol 2 No 1 (2018) Page $70-75$

JURNAL OBSESI : JURNAL PENDIDIKAN ANAK USIA DINI

Research \& Learning in Early Childhood Education

https://obsesi.or.id/index.php/obsesi

\title{
Pengaruh Permainan Building Block terhadap Kecerdasan Visual Anak di TK Ulil Albab Kota Bandung
}

\author{
Ira Hastuti ${ }^{1}$, Anita Santia ${ }^{2 \bowtie}$ \\ Program Studi PG-PAUD, FIP, IKIP Siliwangi
}

\begin{abstract}
Abstrak
Tujuan penelitian dalam artikel ini adalah untuk mengetahui pengaruh permainan building block terhadap kecerdasan visual anak usia dini di TK Ulil Albab Kota Bandung. Permainan building block adalah permainan konstruksional dimana anak usia dini dapat mengembangkan keterampilan dan imajinasi kreatifnya dalam membuat sebuah bangunan dari berbagai bentuk lego. Rumusan masalah dalam penelitian ini adalah bagaimana pengaruh permainan building block terhadap kecerdasan visual anak usia dini di TK Ulil Albab Kota Bandung. Metode penelitian yang digunakan adalah metode penelitian eksperimen. Jenis penelitian eksperimen yang peneliti gunakan adalah one-group pretest posttest design. Hasil penelitian menunjukkan bahwa dengan permainan building block berpengaruh secara signifikan dalam menstimulasi kecerdasan visual anak usia dini di TK Ulil Albab Kota Bandung. Hasil tersebut berdasarkan uji t dengan taraf signifikansi $\alpha=0,05 \mathrm{dan} \mathrm{dk}=12$, dimana nilai $\mathrm{t}$ hitung > t tabel, yaitu 17, 46>11,7 dimana H0 ditolak dan H1 diterima. Artinya, permainan building block berpengaruh secara signifikan dalam menstimulasi kecerdasan visual anak usia dini di TK Ulil Albab Kota Bandung.
\end{abstract}

Kata Kunci: kecerdasan visual, building block, anak usia dini.

\begin{abstract}
The purpose of research is to determine the effect of building block games on visual intelligence early childhood in kindergarten Ulil Albab Bandung. The game building block is a constructive game where early childhood can develop their creative skills and imagination in making a building of various forms of lego. The research problem is how the influence of building block game to visual intelligence of early child in kindergarten Ulil Albab Bandung. The research method used is experimental research method. The type of experimental research that researchers use is one-group pretest posttest design. The results showed that with game building block significantly influence in stimulating visual intelligence of early child in kindergarten Ulil Albab Bandung. The result is based on t test with significance level $\alpha=0,05$ and $\mathrm{dk}=12$, where $\mathrm{t}$ count value $>\mathrm{t}$ table, that is $17,46>11,7$ where $\mathrm{H} 0$ is rejected and $\mathrm{H} 1$ accepted. That is, the game building block significantly influence in stimulating visual intelligence early childhood in kindergarten Ulil Albab Bandung.
\end{abstract}

Keywords: visual intelligence, building block, early childhood.

@ Jurnal Obsesi Prodi PG-PAUD FIP UPTT 2018

$\triangle$ Corresponding author: Anita Santia

Address : PG-PAUD, FIP IKIP Siliwangi

Email : anitashantia07@gmail.com

ISSN 2356-1327 (Media Cetak)

Phone : 085215207015

ISSN 2549-8959 (Media Online) 


\section{PENDAHULUAN}

Pendidikan Anak Usia Dini (PAUD) merupakan pendidikan yang paling mendasar dan menempati kedudukan sebagai masa golden age dan sangat strategis dalam pengembangan sumber daya manusia (Direktorat PAUD, 2005). Dalam UndangUndang Republik Indonesia Nomor 20 Tahun 2003 tentang Sistem Pendidikan Nasional Bab 1 pasal 1 ayat 14 , menegaskan bahwa "Pendidikan Anak Usia Dini adalah suatu upaya pembinaan yang ditujukan kepada anak sejak lahir sampai dengan usia 6 tahun yang dilakukan melalui pemberian rangsangan pendidikan untuk membantu pertumbuhan dan perkembangan jasmani dan rohani agar anak memiliki kesiapan dalam memasuki pendidikan lebih lanjut".

PAUD pada dasarnya harus meliputi aspek keilmuan yang menunjang kehidupan anak dan terkait dengan perkembangan anak. Berdasarkan konsep multiple intelligence, dalam setiap anak memiliki 9 kecerdasan yang meliputi: (1) kecerdasan linguistik, adalah kecerdasan dalam mengelolah kata, (2) kecerdasan logikamatematika, adalah kecerdasan dalam hal angka, (3) kecerdasan fisik-kinestetik, adalah suatu kecerdasan yang melakukan gerakan-gerakan yang bagus, (4) kecerdasan visual-spasial, merupakan salah satu bagian dari kecerdasan jamak yang berhubungan erat dengan kecerdasan untuk memvisualisasikan gambar didalam pikiran seseorang, (5) kecerdasan intrapersonal, adalah kecerdasan diri kita untuk berpikir secara reflektif, (6) kecerdasan interpersonal adalah berpikir lewat berkomunikasi dengan orang lain, (7) kecerdasan musikal yaitu kecerdasan mengenai bentuk-bentuk musikal, (8) kecerdasan naturalis yaitu keahlian mengenali dan mengkategorikan spesies di lingkungan sekitar, (9) kecerdasan spritual adalah kecerdasan dalam memandang makna dan hakikat kehidupan ini semua dengan kodrat manusia sebagai mahluk Tuhan Yang Maha Esa (Lina, 2016).

Dari 9 kecerdasan yang telah diungkapkan, salah satu kecerdasan tersebut yang dapat membantu anak dalam proses belajar serta mengenali lingkungan sekitarnya khususnya dengan berimajinasi, mengenal bentuk, ukuran dan warna, yaitu kecerdasan visual.

Kecerdasan visual adalah kecerdasan yang berkaitan dengan kepekaan dalam memadukan kegiatan persepsi visual (mata) maupun pikiran serta kecerdasan mentransformasikan persepsi visual-spasial seperti yang dilakukan dalam kegiatan melukis, mendesain pola, dan merancang bangunan. Kecerdasan ini melibatkan kepekaan terhadap warna, garis, bentuk, ukuran, luas, dan hubungan-hubungan yang ada diantara unsur-unsur itu (Joni, 2015).

Menurut Lina (2016) kecerdasan visualspasial pada anak usia dini dapat dikembangkan dengan berbagai cara, salah satunya adalah mengatur dan merancang kejelian anak untuk mengatur dan merancang, juga dapat diasah dengan mengajaknya dalam kegiatan mengatur ruang di rumah. Kegiatan seperti ini juga baik untuk meningkatkan kepercayaan diri anak, bahwa ia mampu memutuskan sesuatu.

Berdasarkan uraian yang telah diungkapkan, anak-anak yang mengetahui bentuk, ukuran dan warna adalah anak-anak yang cenderung memiliki kecerdasan visual, banyak sekali manfaat untuk anak mempelajari bentuk, ukuran dan warna, Jadi untuk meningkatkan kecerdasan visual anak dapat dikembangkan dengan permainan building block berdasarkan konsep bentuk, ukuran dan warna. Menurut Masnipal (2013), banyak sekali manfaat dari bermain building block bagi perkembangan anak, baik fisik dan koordinasi otot, emosi, ekspresi kreatif, perkembangan indra, dan belajar konsep bentuk, ukuran, dan nilai jumlah.

Fauziddin menyatakan bahwa fungsi bermain bagi anak usia dini dapat dijadikan intervensi yang jika dilaksanakan dengan tepat, baik dilengkapi dengan alat maupun tanpa alat akan sangat membantu perkembangan sosial, emosional, kognitif, dan afektifnya. (Fauziddin, 2016)

Dengan bermain building block tidak hanya mengasah kecerdasan visual anak, tetapi juga dapat mengembangkan ekspresi kreatif, belajar kognitif, keterampilan kognitif, keterampilan manipulatif, dan imajinasi. Building (membangun) juga sangat bagus untuk perkembangan anak dalam berimajinasi dan merancang. Oleh karena itu sangat disarankan apabila anak-anak melakukan kegiatan membangun atau merancang. Balok dipilih sebagai alat untuk anak-anak bermain karena anak-anak menyukai permainan merancangan bangunan.

Berdasarkan hasil observasi yang dilakukan pada bulan Februari s/d April 2018 di TK Ulil Albab Kota Bandung, ditemukan 
bahwa dari 13 orang anak, hanya 2 orang anak yang dapat mengenal warna dengan benar dan tidak ragu lagi, pada aspek mengenal ukuran, nama bentuk dan menuangkan ide dalam bentuk merancang, semua anak masih mengalami kesulitan dimana semua anak masih belum berkembang.

Penelitian serupa telah dilakukan oleh Juli (2014) dengan judul "Meningkatkan Kecerdasan Visual-Spasial Anak Usia Dini Dengan Metode Bermain Building-Block Pada Kelompok B6 Di Taman Kanak-Kanak Dharma Wanita Persatuan Provinsi Bengkulu" menunjukkan hasil penelitian nya mengalami peningkatan disetiap pertemuannya. Penelitian ini telah membuktikan bahwa dengan metode penelitian serupa juga dilakukan oleh Amelia (2015) dalam "Model Stimulasi Kecerdasan Visual Spasial Dan Kecerdasan Kinestetik Anak Usia Dini Melalui Metode Kindergarten Watching Siaga Bencana Gempa Bumi Di PAUD Terpadu Permata Hati Banda Aceh". Hasil penelitian diperoleh nilai $\mathrm{R}$ square $=0,620$, dan 0,622, yang berarti keterampilan berpengaruh terhadap kecerdasan visual spasial sebesar $62,2 \%$ dan keterampilan berpengaruh terhadap kecerdasan kinestetik sebesar $62 \%$, sehingga dapat disimpulkan bahwa terdapat pengaruh stimulasi kecerdasan visual spasial dan kecerdasan kinestetik anak usia dini melalui metode kindergarten watching siaga bencana gempa bumi di PAUD Terpadu Permata Hati Banda Aceh meskipun pertama kali uji coba.

Berdasarkan uraian sebelumnya, visual anak usia dini sangat penting dan dapat distimulasikan melalui permainan building block. Dengan demikian, maka peneliti tertarik untuk melakukan penelitian yang berjudul "Pengaruh Permainan Building Block terhadap Kecerdasan Visual Anak Usia Dini di TK Ulil Albab Kota Bandung”.

Berdasarkan latar belakang penelitian yang telah diungkapkan, maka rumusan masalah dalam penelitian ini adalah "Bagaimana Pengaruh Permainan Building Block terhadap Kecerdasan Visual Anak Usia Dini di TK Ulil Albab Kota Bandung?". Adapun tujuan penelitiannya adalah untuk mengetahui pengaruh permainan building block terhadap kecerdasan visual anak usia dini di TK Ulil Albab Kota Bandung.
Menurut Kend (2006), Block adalah alat yang bermanfaat untuk mengajarkan anak usia dini tentang konsep ukuran, bentuk, dan warna. Selanjutnya dikemukakan oleh Musrifoh (2005) balok merupakan potongan kayu yang memiliki berbagai bentuk. Umumnya berbentuk segiempat atau kubus, balok, apapun jenisnya digunakan anak membuat bentuk konstruksi atau bangunan. Building adalah kegiatan konstruksional proses membangun, melalui permainan konstruksional anak-anak dapat mengembangkan ekspresi kreatif, belajar kognitif, keterampilan kognitif, keterampilan manipulatif, imajinasi dan aspek dramatis (Joni, 2015).

Dari uraian tersebut dapat disimpulkan bahwa bermain building block adalah permainan konstruksional dimana anak usia dini dapat mengembangkan keterampilan dan imajinasi kreatifnya dalam membuat/merancang sebuah bangunan dari berbagai bentuk-bentuk balok- balok tersebut. Menurut Musfiroh (2008) aspek dari kecerdasan visual adalah kepekaan terhadap bentuk, unsur bentuk, ukuran, komposisi, dan warna. Mereka yang cerdas visual sangat imajinatif mampu membayangkan sesuatu dengan detil, senang membuat kontruksi tiga dimensi dari unsur, seperti: lego, brick, bombiq, dan balok dan juga mereka belajar dengan melihat dan mengamati benda, bentuk, dan warna.

Menurut Luluk (2008) ada tiga tahap perkembangan anak dalam penggunaan balok yaitu: Tahap 1: membawa bentuk balok (bermain fungsional), pada tahap ini anak yang belum pernah bermain balok sebelumya anak akan membawa balok tersebut kedalam truk, pada saat ini anak akan tertarik untuk mempelajari tentang balok-balok, dengan mengalami hal-hal tersebut, anak mulai belajar tentang balok-balok yang dapat digunakannya dan memiliki pengetahuan tentang apa yang dapat dan apa yang tidak dapat ia lakukan dengan balok. Tahap 2, menumpuk bentuk balok dan meletakannya di lantai. Pada tahapan ini, anak menemukan bagaimana caranya membuat menara dengan menumpuk balok dan bagaimana kelihatannya jika diletakan di lantai dan juga pada tahap ini anak mulai menerapkan khayalan dan kecerdasan kritis.

Tahap 3, menghubungkan bentuk balok untuk membuat bangunan, pada tahapan ini, anak usia dini menandai transisi dari hanya 
menumpuk balok kepada membuat bangunan yang nyata. Anak usia dini yang telah terbiasa dengan bangunan jalan menemukan bahwa mereka dapat mengunakan jalan untuk menghubungkan menara-menara. Penemuan ini membawa anak kepada tahap percobaan aktif ketika anak menerapkan kecerdasan memecahkan masalah. Biasanya pada tahap 3 ini anak telah memiliki barbagai pengalaman dengan balok, pengalaman ini membuat mereka mampu menggunakan balok dengan cara-cara baru yang kreatif.

Tahap 4, membuat bangunan yang jelas terlihat (bermain dramatik), anak usia dini yang berpengalaman dengan balok (4-6 tahun) dapat meletakan balok dengan menggunakan keterampilan dan ketelitian, anak belajar beradaptasi pada bangunan mereka dengan membuat struktur dengan membuat bangunan balok ke atas, kesekeliling atau di atas penghalang. Pada tahap empat anak mulai ahli dalam membuat susunan yang kompleks dan tidak mencontoh karya orang lain (hasil buatan sendiri).

Selama tahap perkembangan ini anak membutuhkan balok-balok dengan variasi ukuran dan bentuk balok sehingga mereka dapat membuat bangunan yang lebih lengkap. Tanda lain dari tahapan ini adalah anak dapat menamai atau memberi tanda bangunannya yang sering digunakan untuk bermain dramatik.

\section{METODE}

Rancangan penelitian yang digunakan adalah metode penelitian eksperimen. Sesuai dengan tujuan penelitian ini, yaitu untuk mengetahui pengaruh permainan building block terhadap kecerdasan anak usia dini di TK Ulil Albab Kota Bandung. Jenis penelitian eksperimen yang peneliti gunakan yaitu onegroup pretest posttest design yaitu satu kelompok eksperimen diukur variabel dependennya (pretest), kemudian diberikan kegiatan pembelajaran dengan menerapkan permainan building block dalam menstimulasi kecerdasan visual anak usia dini untuk mengenal bentuk-bentuk geometri di TK Ulil Albab, dan diukur kembali variabel dependennya (posttest), tanpa ada kelompok pembanding.

Tes ini diberikan untuk mengetahui kecerdasan atau penguasaan suatu materi yang telah dipahami oleh anak dan untuk melihat apakah permainan building block berpengaruh terhadap kecerdasan visual anak usia dini di
TK Ulil Albab. Populasi dalam penelitian ini adalah seluruh anak di TK Ulil Albab.

Berdasarkan informasi dari guru kelas di TK tersebut, maka yang menjadi sampel dalam penelitian ini adalah berjumlah 13 anak. Instrumen dalam penelitian ini adalah soal tes dan lembar observasi. Soal tes berbentuk tulisan dengan jumlah soal 12 butir pertanyaan yang terdiri 6 soal pretest dan 6 soal posttest. Pengelolahan data dalam penelitian ini dengan menggunakan rumus statistika yang bertujuan untuk mengetahui pengaruh permainan building block terhadap kecerdasan visual anak usia dini di TK Ulil Albab.

Untuk mengetahui analisis data kuantitatif secara uji hipotesis yaitu menggunakan rumus pretest dan posttest one group design. Adapun rumus dan analisis hasilnya menggunakan bantuan software SPSS v.19.

Untuk menguji hipotesis yang telah dirumuskan dilakukan dengan menggunakan statistik uji t. Adapun hipotesis yang diuji adalah pengaruh permainan building block terhadap kecerdasan visual pada anak usia dini di TK Ulil Albab Kota Bandung.

Hipotesis statistik:

1) $\mathrm{H} 0=\mu 0=\mu 0$ : Permainan Building Block tidak berpengaruh terhadap kecerdasan visual anak usia dini di TK Ulil Albab Kota Bandung. 2) $\mathrm{H} 1=\mu 1>\mu 2$ :Permainan Building Block berpengaruh terhadap kecerdasan visual anak usia dini di TK Ulil Albab Kota Bandung.

Adapun kriteria yang digunakan dalam penelitian ini adalah: Terima $\mathrm{H} 0$ jika $-\mathrm{t}-12 \alpha$ $(\mathrm{n}-1)<\mathrm{t}$ tabel $\mathrm{t} 1-12 \alpha(\mathrm{n}-1) \mathrm{t}$ tabel dan tolak $\mathrm{H} 0$ jika $\mathrm{t}$ mempunyai nilai yang lain. Adapun dalam pelaksanaan permainan building block terhadap kecerdasan visual dilakukan berhasil jika pembelajaran minimal mencapai $76 \%$ yang berarti (Berkembang Sangat Baik/BSB) dari jumlah anak yang ada di kelas yang dirumuskan dalam setiap keberhasilan pembelajaran berpedoman penilaian hasil kemampuan anak dalam persiapan yang disampaikan oleh guru.

Untuk mengetahui analisis data deskriptif, menggunakan rumus statistik sebagai berikut:

Data hasil pengamatan aktivitas dideskripsikan untuk setiap pertemuan dan dilihat kecenderungannya dalam bentuk persentase dengan menggunakan rumus sebagai berikut:

$$
\mathrm{P}=\frac{F}{N} \times 100 \%
$$


74 | Pengaruh Permainan Building Block terhadap Kecerdasan Visual Anak di TK Ulil Albab Kota Bandung

Keterangan:

$\mathrm{P}=$ Persentase

$\mathrm{F}=$ Frekuensi

$\mathrm{N}=$ Jumlah siswa

\section{HASIL DAN PEMBAHASAN}

Hasil rekapan kegiatan saat pretest dan postest dapat dilihat pada tabel berikut:

Tabel 1. Tabel Nilai Pretest dan Postes Anak

\begin{tabular}{|c|c|c|c|}
\hline \multirow{2}{*}{ No. } & \multirow{2}{*}{ Kode Anak } & \multicolumn{2}{|c|}{ Penilaian } \\
\cline { 3 - 4 } & & Pretest & Postest \\
\hline 1 & SAZ & 65 & 80 \\
\hline 2 & NS & 60 & 75 \\
\hline 3 & AS & 70 & 80 \\
\hline 4 & MA & 85 & 95 \\
\hline 5 & AM & 75 & 85 \\
\hline 6 & RK & 70 & 85 \\
\hline 7 & MR & 85 & 95 \\
\hline 8 & AK & 70 & 85 \\
\hline 9 & FM & 75 & 85 \\
\hline 10 & MJ & 80 & 90 \\
\hline 11 & IZ & 85 & 95 \\
\hline 12 & EA & 75 & 85 \\
\hline 13 & MRH & 80 & 90 \\
\hline
\end{tabular}

Tabel 2. Tabel Nilai Rata-rata Pretest Anak

\begin{tabular}{|c|c|c|c|c|c|}
\hline \multirow{2}{*}{ No. } & Kode & \multicolumn{4}{|c|}{ Penilaian } \\
\hline & Anak & BB & MB & BSH & BSB \\
\hline 1 & SAZ & & V & & \\
\hline 2 & NS & & V & & \\
\hline 3 & AS & & & V & \\
\hline 4 & MA & & & & V \\
\hline 5 & AM & & & V & \\
\hline 6 & RK & & & V & \\
\hline 7 & MR & & & & V \\
\hline 8 & AK & & & V & \\
\hline 9 & FM & & & V & \\
\hline 10 & MJ & & & & V \\
\hline 11 & IZ & & & & V \\
\hline 12 & EA & & & V & \\
\hline 13 & MRH & & & & V \\
\hline
\end{tabular}

Tabel 3. Tabel Nilai Rata-rata Postest Anak

\begin{tabular}{|c|c|c|c|c|c|}
\hline \multirow{2}{*}{ No. } & Kode & \multicolumn{5}{|c|}{ Penilaian } \\
\hline & Anak & BB & MB & BSH & BSB \\
\hline 1 & SAZ & & & & V \\
\hline 2 & NS & & & V & \\
\hline 3 & AS & & & & V \\
\hline 4 & MA & & & & V \\
\hline 5 & AM & & & & V \\
\hline 6 & RK & & & & V \\
\hline 7 & MR & & & & V \\
\hline 8 & AK & & & & V \\
\hline 9 & FM & & & & V \\
\hline 10 & MJ & & & & V \\
\hline 11 & IZ & & & & V \\
\hline 12 & EA & & & & V \\
\hline 13 & MRH & & & & V \\
\hline
\end{tabular}

Berdasarkan hasil penelitian, dapat dinyatakan bahwa permainan building block berpengaruh terhadap kecerdasan visual anak usia dini TK Ulil Albab Kota Bandung. Pelaksanaan dalam kegiatan penelitian ini yaitu bermain building block selama tiga kali pertemuan. Tahapan pelaksanaannya yaitu pretest, tindakan eksperimen dan postest. Hasil perhitungan penelitian diperoleh nilai thitung $=17,46$. Untuk membandingkan dengan $\mathrm{t}$ tabel, maka perlu dicari dahulu derajat kebebasan dengan menggunakan rumus yaitu: $\mathrm{Dk}=13-1=12$. Berdasarkan pada taraf signifikan $\alpha=0,05$ dan $\mathrm{dk}=12$ dengan kriteria terima $\mathrm{H} 0$ jika $=-12 \alpha(\mathrm{n}-1) \mathrm{t}$ tabel $=\mathrm{t}(1-$ $0,025)(12)=\mathrm{t}(0,975)(12)=11,7$, tolak H0 jika t mempunyai nilai yang lain. Dari tabel distribusi diperoleh $\mathrm{t}(0,975)(12)=11,7$, karena $t$ hitung memenuhi kriteria $-\mathrm{t}-12 \alpha$ (n1) $<\mathrm{t}$ tabel $\mathrm{t} 1-12 \alpha(\mathrm{n}-1)(\mathrm{t}$ hitung $>\mathrm{t}$ tabel $)=$ 17, $46>11,7$ maka $\mathrm{H} 0$ ditolak dan $\mathrm{H} 1$ diterima. Artinya, permainan building block berpengaruh terhadap kecerdasan visual anak usia dini TK Ulil Albab Kota Bandung.

Selanjutnya, apabila dilihat rata-rata akhir anak yang diberikan pembelajaran dengan menggunakan permainan building block sebesar 77 untuk rata-rata pretest, dan 88,53 untuk rata-rata posttest. Hal ini menunjukkan bahwa pembelajaran anak usia dini dengan menggunakan permainan building block terdapat pengaruh terhadap kecerdasan visual.

Berdasarkan hasil observasi, terlihat bahwa 13 anak yang menjadi subjek penelitian, $85 \%$ anak yang masuk dalam kategori Berkembang Sangat Baik (BSB); 19,22\% anak yang masuk dalam kategori Berkembang 
Sesuai Harapan (BSH), 5,76\% anak yang masuk dalam kategori Mulai Berkembang (MB), dan 1,92\% anak yang masuk dalam kategori Belum Berkembang (BB). Hasil penelitian ini sejalan dengan pendapat Masnipal (2013) yang mengemukakan bahwa bermain balok memberikan manfaat yang luas bagi perkembangan anak, baik fisik dan koordinasi otot, emosi, sosial, ekspresi kreatif, perkembangan indra, dan belajar konsep bentuk, ukuran dan nilai jumlah.

Masnipal (2013) juga menyatakan bahwa bermain dengan balok memberikan anak-anak sebuah kesempatan untuk menciptakan gambar dalam bentuk kongkrit. Kecerdasan menciptakan ini merupakan representasi dari pengalaman yang merupakan basis baru dari berpikir abstrak, selain itu bermain balok juga dapat meningkatkan pemahaman kongkrit dari konsep penting pada berpikir logika dan anak belajar tentang ukuran, bentuk, jumlah, area, panjang, pola, dan berat dalam membangun struktur dapat merangsang kreativitas mereka.

\section{UCAPAN TERIMA KASIH}

Ketua peneliti beserta anggota mengucapkan terimakasih banyak kepada Tim dan TK Ulil Albab Kota Bandung atas kerjasama yang baik selama penelitian ini dilakukan serta Bapak Dr. Ramdhan Witarsa, M.Pd. sebagai pembimbing dalam menulis artikel ini hingga dipublikasikan. Semoga amal baik kita semua diterima Allah SWT.

\section{SIMPULAN}

Berdasarkan hasil penelitian dan pembahasan, maka dapat disimpulkan bahwa permainan building block berpengaruh terhadap kecerdasan visual anak usia dini TK Ulili Albab Kota Bandung. Pada tes awal anakanak masih banyak yang mendapatkan nilai rata-rata MB 2 anak, BSH 6 anak, dan BSB 5 orang anak. Pada tes akhir, anak-anak banyak yang mendapatkan nilai rata-rata BSH 2 anak, dan BSB 11 orang anak.

\section{DAFTAR PUSTAKA}

Amelia, L. (2015). Stimulasi Kecerdasan Visual Spasial dan Kecerdasan Kinestetik Anak Usia Dini Melalui Metode Kindergarten Watching Siaga Bencana Gempa Bumi di PAUD Terpadu Permata Hati Banda Aceh. Ejournal STKIP BBG.
Fauziddin, M. (2016). Penerapan Belajar Melalui Bermain dalam Meningkatkan Kreativitas Anak Usia Dini . Curricula, l(3). https://doi.org/10.22216/JCC.2016.v2i3.1 277

Joni (2015). Hubungan Pola Asuh Orang Tua terhadap Perkembangan Bahasa Anak Prasekolah (3-5 tahun) di PAUD AlHasanah Tahun 2014. Journal Obsesi (Journal of Early Chilhood Education, $1(1), 42-48$.

Kend. (2006). Main dan Permainan Anak Usia Dini. Jakarta: Gramedia.

Lina, A. (2016) Stimulasi Kecerdasan Visual Spasial dan Kecerdasan Kinestetik Anak Usia Dini Melalui Metode Kindergarten Watching Siaga Bencana Gempa Bumi di PAUD Terpadu Permata Hati Banda Aceh. jurnal visipena vol. 6 no. 2 hal 26-39

Luluk, dkk. (2008). Pengelolahan Kegiatan Pengembangan Anak Usia Dini. Penerbit: Universitas Terbuka.

Masnipal. (2013). Siap Menjadi Guru dan Penggelola PAUD Propesional. Jakarta: Kompas Gramedia.

Mulyasa, E. (2009). Praktik Penelitian Tindakan Kelas. Bandung: Prenada Media.

Musfiroh, T. (2005). Bermain Sambil Belajar dan Mengasah Kecerdasan. Jakarta: PT Indeks.

Musfiroh. (2008). Pengembangan Kecerdasan Majemuk. Jakarta: Universitas Terbuka.

Undang-undang Sisdiknas. (2003). Pendidikan Anak Usia Dini. Jakarta: Depdiknas. 